\title{
Melayu di Atas Tiga Bendera: Konstruksi Identitas Nasionalisme Masyarakat Perbatasan di Kepulauan Batam
}

\author{
Adek Risma Dedees ${ }^{*}$
}

\begin{abstract}
This paper describes the construction of nationalism identities of the border communities in the islands of Batam. This research employed a qualitative-interpretive method, with respondents' statements, stories, and views towards the idea of border communities' nationalism as the units of analysis. The results of this study explains that the border communities in Batam Islands profess to love and support Indonesia in an ambivalent manner, because simultaneously it coincides with Malay and their Malayanism as a raison d'etre across countries. This ambivalent nationalism is due to their affinity and closeness from being fellow Malayan; a relationship that defeats the power of countries ideologies and territories that separate the border communities in Indonesia, Singapore and Malaysia. The shared historical and cultural experience is what gives color, shade, or uniqueness to the border communities in Batam Islands when imagining or defining nationalism.
\end{abstract}

\section{Keywords:}

nationalism; border communities; Batam Islands; Malay.

\begin{abstract}
Abstrak
Tulisan ini menjelaskan tentang konstruksi identitas nasionalisme masyarakat perbatasan di Kepulauan Batam. Jenis penelitian ini adalah kualitatif-interpretatif, dengan unit analisa pernyataan-pernyataan, cerita-cerita, dan pandangan informan tentang bayangan nasionalisme masyarakat perbatasan. Hasil penelitian ini menjelaskan bahwa masyarakat perbatasan di Kepulauan Batam mengaku mencintai dan membela Indonesia dengan kondisi yang 'terbelah', karena pada saat yang bersamaan juga beririsan dengan Melayu dan kemelayuan sebagai raison d'etre yang sifatnya lintas negara. Nasionalisme yang 'terbelah' ini disebabkan karena pertalian dan kedekatan bersama di bawah payung Melayu yang mampu mengalahkan kekuatan ideologi negara dan teritori yang memisahkan masyarakat perbatasan, baik Indonesia, Singapura maupun Malaysia. Pengalaman sejarah dan pengalaman kultural bersama inilah yang kemudian memberikan warna, corak, atau kekhasan tersendiri bagi masyarakat perbatasan di Kepulauan Batam ketika membayangkan atau mendefiniskan nasionalisme tersebut.
\end{abstract}

\section{Kata kunci:}

nasionalisme; masyarakat perbatasan; Kepulauan Batam; Melayu.

\footnotetext{
- Mahasiswa Pascasarjana Departemen Politik dan Pemerintahan, FISIPOL UGM

Email: adedees@gmail.com
} 


\section{Pendahuluan}

Makalah ini mengkaji tentang konstruksi identitas nasionalisme masyarakat perbatasan di salah satu kawasan pulau terdepan di kepulauan Indonesia. Wacana nasionalisme kerap kali menjadi isu yang rentan dimainkan, dinegosiasikan dan dibicarakan di kawasan perbatasan. Hal ini dikarenakan masyarakat di kawasan perbatasan memiliki karakteristik yang berbeda serta khas jika dibandingkan dengan masyarakat yang tidak berasal dan tinggal di kawasan perbatasan. Masyarakat perbatasan cenderung memiliki tingkat mobilitas yang lebih tinggi untuk berinteraksi dan bersentuhan secara langsung dengan masyarakat lain yang berbeda latar belakang dan kewarganegaraan. Mereka berinteraksi secara sosio-budaya, ekonomi hingga persoalan-persoalan politik. Interaksi yang cukup intens ini melahirkan kecenderungan-kecenderungan yang berbeda dengan masyarakat non-perbatasan. Misalnya, mulai dari penggunaan bahasa asing (bilingual atau multilingual), penggunaan mata uang negara sendiri sekaligus dari negara lain, konsumsi produk-produk negeri luar, keluarmasuk tinggal dan bekerja di negara tetangga dan sebagainya. Berbagai aktivitas tersebut sudah menjadi kegiatan keseharian pada masyarakat perbatasan yang memang tak bisa ditampik dan sudah dilakukan sejak lama, turun temurun oleh masyarakat lokal.

Badan Pusat Statistik Kota Batam mencatat pada tahun 2011 jumlah pengunjung yang datang berkunjung ke Batam adalah 1.186.773 orang. Angka ini meningkat menjadi 1.212.775 orang pada tahun 2012 atau mengalami peningkatan sebesar 2,19 persen. Selanjutnya pada tahun 2013 kembali naik menjadi 1.316 .526 orang atau mengalami kenaikan sebesar 8,55 persen. Warga Singapura merupakan pengunjung dominan, yaitu sebesar 59,11 persen. Kemudian posisi kedua dan ketiga ditempati oleh pengunjung dari Malaysia dan Korea Selatan masing-masing sebesar 15,93 dan 4,38 persen (Batam dalam Angka, 2014).
Kedatangan WNA (Warga Negara Asing) ini dicatat sebagai wisatawan yang melancong ke Kepulauan Batam. Kedatangan warga asing ini ada yang murni berwisata ke Kepulauan Batam, ada pula yang mengunjungi sanak famili.

Daerah perbatasan Indonesia yang bersangkut paut dengan negara lain di dunia tak lepas dari problematika yang biasa ditemui di perbatasan. Terlebih lagi Indonesia merupakan negara kepulauan terbesar di dunia yang terletak pada dua benua besar dan dua samudera besar (Marsetio, 2012). Pendayagunaan daerah perbatasan khususnya area laut memiliki arti penting terhadap kedaulatan dan keutuhan Negara Kesatuan Republik Indonesia. Dari perspektif dalam negeri, ada tantangan yang harus dihadapi, misalnya isu-isu peningkatan nasionalisme masyarakat perbatasan, peningkatan kualitas sumberdaya manusia, perbaikan infrastruktur, serta perbaikan kualitas hidup menjadi fokus perdebatan yang tidak kunjung selesai. Sementara itu, keberadaan daerah perbatasan menjadi beban tersendiri di dalam perdebatan pembangunan yang diakibatkan oleh rentannya posisi daerah perbatasan dalam berbagai dimensi. Tingkat migrasi ke luar negeri di daerah-daerah perbatasan sangat tinggi, bahkan mengkhawatirkan jika melihat fakta banyaknya masyarakat daerah perbatasan yang bekerja di luar negeri, serta berpindah kewarganegaraan. Loyalitas masyarakat terhadap negaranya selalu menjadi pertanyaan penting yang membutuhkan jawaban kebijakan substansial.

Di sepanjang garis batas darat atau laut daerah suatu negara, kerap terjadi asimilasi di daerah yang dikenal dengan frontier, daerah perbatasan yang mendapat lebih banyak pengaruh negara asing dari seberang batas negara. Interaksi dinamis antara dua budaya atau lebih dapat membentuk satu batas semu dan cenderung abstrak yang berbeda letaknya secara geografis dengan batas aslinya. 
Frontier ini bersifat sangat dinamis, dalam arti dapat bergeser-geser, dan dapat dikatakan bahwa efektivitas pemerintah pusat tidak lagi mencakup seluruh daerah kedaulatan secara penuh, melainkan dikurangi luar daerah yang sudah dipengaruhi oleh kekuatan 'asing' dari seberang, entah melalui politik, ekonomi, dan sosial budaya (Sunardi, 2004). Beberapa ciri khas masyarakat perbatasan di Pulau Batam yakni: masyarakatnya heterogen dari berbagai suku bangsa dan agama yang tersebar hidup bermukim di pulau kecil sekitar Pulau Batam.

Sensus Penduduk Tahun 2000 mencatat jumlah penduduk Kota Batam berdasarkan etnisitas terdiri atas suku Jawa 26,78 persen, Melayu 17,61 persen, Batak 14,97 persen, Minangkabau 14,93 persen, Tionghoa 6,28 persen, Bugis 2,29 persen, Banjar 0,67 persen, dan suku lainnya sebesar 16,47 persen. Sedangkan berdasarkan jumlah penganut agama, penganut Islam sebanyak 76,69 persen, Kristen 17,02 persen , Budha 5,79 persen dan Hindu 0,40 persen. Komposisi etnisitas ini menarik dicermati pada penelitian lapangan karena tidak sedikit orang-orang Jawa yang sudah menikah dan bercampurbaur dengan orang-orang Melayu, menjadi dan mengaku sebagai orang Melayu. Sementara itu, heterogenitas ini berimplikasi terhadap kontestasi dalam mengkonstruksi identitas pada masyarakat perbatasan. Berbagai bentuk daerah perbatasan dapat dikonstruksi atau terkonstruksi oleh negara. Pada saat yang sama kelompok-kelompok sosial atau masyarakat juga bisa mempunyai daerah perbatasannya sendiri, yang berbeda dengan kelompok lain. Daerah perbatasan kelompok sosial mempunyai logika dan identitasnya sendiri. Mereka juga mempunyai dimensi ke-identitas-an sendiri yang berbeda dengan definisi negara.

Penelitian ini akan mengkaji konstruksi identitas nasionalisme masyarakat perbatasan di Kepulauan Batam. Kawasan ini dipilih karena faktor sosial-budaya yang masih berkaitan dengan dua negara lain yakni Singapura dan Malaysia. Kepulauan ini juga berfungsi sebagai sebagai kawasan industri strategis nasional dan kawasan industri penyangga bagi negara lain. Berdasarkan latar belakang itulah makalah ini dibangun dengan dua rumusan penelitian yaitu, (1) bagaimana konstruksi identitas nasionalisme masyarakat perbatasan di Kepulauan Batam? (2) instrumen sosialbudaya dan ekonomi-politik seperti apa yang dipakai oleh masyarakat perbatasan dalam proses konstruksi bayangan nasionalisme di Kepulauan Batam?

\section{Metodologi Penelitian}

Studi ini menggunakan metode penelitian kualitatif-interpretatif untuk menjelaskan konstruksi identitas ke-Indonesia-an masyarakat perbatasan di Kepulauan Batam. Sebagai studi kasus, penelitian ini menjadikan hasil wawancara dengan informan dari berbagai latar belakang suku, usia, gender, dan pendidikan sebagai data utama. Selain itu, pengamatan lapangan dan kajian pustaka melengkapi kajian ini. Penelitian ini berusaha mengidentifikasi, mendeskripsikan dan menginterpretasikan pola-pola umum, kecenderungan-kecenderungan dan tematema dari data yang diperoleh. Data tersebut kemudian dianalisis melalui penguraian dan pengonsepan sesuai dengan kerangka teori yang ada, lalu membuat kesimpulan penelitian

\section{Negara, Kebangsaan, dan Nasionalisme}

Negara-bangsa, nasionalisme, dan identitas nasional sebagai bentuk organisasi kolektif dan mengidentifikasinya bukanlah fenomena yang terjadi 'secara alamiah', melainkan formasi kultural-historis yang dinamik. Negara-bangsa adalah konsep politis yang mengacu pada administrative apparatus yang dipercaya memiliki kedaulatan atas daerah atau daerah tertentu dalam sistem negara-bangsa. Identitas nasional adalah 
bentuk identifikasi imajinatif terhadap simbol dan diskursus negara-bangsa. Jadi, bangsa bukan hanya sekadar formasi politis, melainkan sistem representasi kultural di mana identitas nasional terus menerus direproduksi sebagai tindakan diskursif (Barker, 2000).

Demikian pula yang dikatakan oleh Bennedict Anderson ketika menjelaskan identitas kebangsaan. Dengan menggunakan cara berpikir antropologis, ia mengusulkan definisi tentang bangsa (nation), yaitu komunitas politis dan dibayangkan sebagai sesuatu yang bersifat terbatas secara inheren sekaligus berkedaulatan (Anderson, 2001). Lebih lanjut Anderson menjelaskan, bangsa adalah sesuatu yang terbayang, karena para anggota bangsa sekecil apa pun tidak bakal tahu dan takkan kenal sebagian besar anggota lain, tidak akan bertatap muka dengan mereka itu, bahkan mungkin tidak pula pernah mendengar tentang mereka. Namun di benak setiap orang yang menjadi anggota bangsa itu hidup ada sebuah bayangan tentang kebersamaan mereka.

Bangsa dibayangkan sebagai sesuatu yang pada hakikatnya bersifat terbatas, karena bahkan bangsa-bangsa yang paling besar pun, memiliki garis-garis perbatasan yang pasti meski elastis. Di luar perbatasan itu adalah bangsa-bangsa lain. Tak satu bangsa pun membayangkan dirinya meliputi seluruh umat manusia di bumi. Bangsa dibayangkan pula sebagai sesuatu yang berdaulat, lantaran konsep itu lahir dalam kurun waktu pencerahan dan revolusi memporak-porandakan keabsahan ranah dinasti berjenjang yang berkaitan dengan kuasa Tuhan. Panji-panji kebebasan ini adalah negara berdaulat. Akhirnya, bangsa dibayangkan sebagai sebuah komunitas, sebab tak peduli akan ketidakadilan yang ada dan penghisapan yang mungkin tak terhapuskan dalam setiap bangsa. Bahkan bangsa itu sendiri selalu dipahami sebagai kesetiakawanan yang masuk mendalam dan melebar-mendatar. Selama dua abad terakhir, rasa persaudaraan inilah yang memungkinkan begitu banyak orang, jutaan jumlahnya, bersedia -jangankan melenyapkan nyawa orang lain- merenggut nyawa sendiri pun rela demi pembayangan tentang yang terbatas itu.

Dengan memahami identitas kebangsaan seperti itu, Anderson menggaris-bawahi, bangsa menjadi proyek untuk dikerjakan, diolah, sehingga bangsa menjadi suatu mode of existence. Bangsa menjadi suatu proyeksi ke depan dan sekaligus ke belakang. Oleh karena itu tidak pernah bisa dikatakan suatu bangsa "lahir", namun bangsa itu "hadir" dalam proses formasi sebagai suatu historical being sebagaimana dikatakan "komunitas-komunitas terbayang". Jadi, menurut Anderson bangsa bukan suatu political community, akan tetapi imagined political community, dan semakin ditekankan lagi ketika dikatakan sebagai imagined as sovereign, imagined as limited dan imagined as community. Konsep identitas kebangsaan ini agaknya mirip dengan konsep identitas kebudayaan yang tidak hanya dibentuk oleh suatu yang statis, melainkan senantiasa berproses dan dinamis dalam diskursus sosial.

\section{Identitas dan Diri}

Secara konseptual subyektivitas dan identitas mempunyai hubungan yang erat dan bahkan tidak dapat dipisahkan. Berbicara tentang subyektivitas, pertanyaannya akan berada seputar apakah pribadi itu? Sementara mengeksplorasi tentang identitas adalah menanyakan: Bagaimana kita melihat diri kita sendiri dan bagaimana orang lain melihat kita? (Barker, 2000). Subyektivitas dan identitas adalah produk kultural yang spesifik dan tidak abadi. Yang dimaksud dengan seorang pribadi adalah seluruh aspek sosial dan kultural. Jadi, identitas sepenuhnya merupakan konstruksi sosial dan tidak mungkin eksis di luar representasi kultural dan akulturalisasi. Kita memandang identitas diekspresikan melalui berbagai bentuk representasi yang dapat dikenali oleh orang lain dan kita 
sendiri. Jadi, identitas adalah suatu 'esensi' yang dapat dimaknai melalui tanda-tanda selera, kepercayaan, sikap dan gaya hidup. Identitas dianggap personal sekaligus sosial dan menandai bahwa kita sama atau berbeda dengan orang lain.

Menurut Anthony Giddens (1991), identitas diri dipahami sebagai keahlian menarasikan tentang diri, dengan demikian menceritakan perasaan yang konsisten tentang kontinuitas biografi. Seseorang berusaha mengkontruksikan cerita identitas yang saling bertalian di mana diri membentuk lintasan perkembangan dari pengalaman masa lalu menuju masa depan. Giddens melanjutkan bahwa identitas diri adalah apa yang kita pikirkan tentang diri tersebut dalam kapasitas sebagai person. Namun, ia juga berargumen bahwa identitas bukan sekumpulan sifat-sifat yang kita miliki; bukan sesuatu yang kita miliki. Dengan demikian, identitas adalah sarana berpikir tentang diri kita sendiri. Hanya saja apa yang kita pikirkan itu senantiasa berubah dari lingkungan satu ke lingkungan lain menurut daerah dan waktu. Inilah sebabnya, mengapa Giddens mendeskripsikan identitas sebagai suatu proyek. Dengan argumen ini ia mengartikan bahwa identitas adalah sesuatu yang kita ciptakan, sesuatu yang senantiasa berproses, yang terus maju ke depan daripada tetap.

Identitas bukan hanya merupakan masalah deskripsi diri, tetapi juga merupakan askripsi sosial. Identitas adalah masalah tentang kesamaan dan perbedaan, tentang personal dan sosial, tentang apa yang anda miliki bersama dengan seseorang dan tentang apa yang membedakan anda dengan lainnya (Weeks, 1990). Guna mengetahui bagaimana masyarakat perbatasan di Kepulauan Batam membayangkan identitas ke-Indonesia-an mereka yakni dengan bagaimana mereka berelasi dengan masyarakat dari negara tetangga secara sosio-budaya dan secara ekonomi-politik. Sejauh mana negara-bangsa itu terbayangkan, tergambarkan dan terpikirkan oleh masyarakat perbatasan yang setiap hari berinteraksi dengan berbagai masyarakat dari berbagai negara.

\section{Mobilitas Penduduk antar-Wilayah di Kawasan Perbatasan}

Dalam perjalanan sejarah di masa lampau, wilayah Kepulauan Riau merupakan bagian yang tidak terpisahkan dari Kerajaan Melayu baik ketika periode Bintan dan Tumasik (Singapura) sekitar penghujung abad ke-14 dan periode Malaka dalam abad ke-15, periode Johor sampai akhir abad ke-16, maupun periode Johor-Riau Lingga abad ke-18 hingga abad ke-20. Selama empat periode, kerajaankerajaan Melayu itu selalu saja menyebut Kepulauan Riau sekarang ini merupakan wilayah utama dan basis-basis ekonomi serta politik mereka (Samad, 2010). Oleh sebab itu, dari segi kultural seperti bahasa, agama, adatistiadat, sistem nilai, struktur sosial dan sistem kekerabatan masyarakat Riau Kepulauan tidak begitu berbeda dengan rumpun Melayu yang ada di negara tetangga Singapura dan Malaysia sekarang ini. Di antara Suku Melayu Riau dan Suku Melayu yang ada di negaranegara tetangga tersebut masih terdapat ikatan kekeluargaan yang relatif kuat yang berakar pada sejarah masa lampau.

Pada masa kolonial kawasan ini bersama dengan daerah Semenanjung Malaya (Malaysia) silih berganti pernah berada dalam taklukan Portugis, Inggris dan Belanda. Menyusul kekalahan Malaka oleh serangan Portugis pada tanggal 10 Agustus 1511 di bawah pimpinan Gubernur Portugis di India, Alfonso de Alberqueque, maka hegemoni kekuasaan yang semula berada pada imperium Melayu di perairan Selat Malaka yang menguasai lalu lintas perdagangan internasional, secara drastis berpindah tangan ke Portugis (Samad, 2010; Reid, 2010). Untuk beberapa lama kemudian pindah ke Belanda dan Inggris. Sebaliknya, Kerajaan Melayu semakin terdesak serta 
pusat kerajaan selalu berpindah dalam usaha menyerang dan mempertahankan diri dari kolonial tersebut. Mula-mula Sultan Mahmud Raja Malaka memindahkan pusat kerajaannya ke Johor begitu Malaka jatuh ke tangan Portugis. Beberapa waktu kemudian setelah Belanda berperanan menggantikan Portugis, pindah lagi ke Bintan, kemudian pindah lagi ke Johor. Semakin terdesak oleh serangan dan tekanan Belanda serta konflik internal dalam kerajaan Johor itu sendiri, pusat kerajaan dipindahkan lagi ke Lingga-Daik dan Pulau Penyengat di Kepulauan Riau sampai akhirnya difalsifikasi Belanda pada tahun 1913 menyusul kekalahan Yang Dipertuan Muda Riau Raja Ali Haji dalam perang dengan Belanda yang kemudian gugur pada 18 Juni 1784 di Teluk Ketapang Malaka.

Baik ketika masih bernama Kerajaan Malaka maupun Johor, daerah Kepulauan Riau sekarang ini tetap menjadi bagian dari Kerajaan Melayu, bahkan untuk kurun waktu yang cukup lama Kepulauan Riau menjadi pusat kerajaan dari imperium Melayu tersebut (Samad, 2010). Baru ketika Traktat London ditandatangani antara Belanda dan Inggris tahun 1824, Johor-Riau menjadi terpisah sesuai dengan isi perjanjian tersebut di mana Sumatera menjadi jajahan Belanda dan Malaysia menjadi taklukan Inggris. Walaupun pola penjajahan negara kolonial tersebut berbeda dan walaupun perjanjian London 1824 tersebut membagi dunia orang Melayu dan membagi Kerajaan Johor lama, memisahkan saudara dengan saudara, kawan dengan kawan, namun hubungan antara Johor dengan Riau tetap kuat dan berlanjut.

Singapura dan Malaysia adalah dua negara tujuan utama bagi masyarakat di Kepulauan Batam yang melakukan perjalanan antar-wilayah di sekitar kawasan perbatasan tersebut. Sebenarnya, arus mobilitas masyarakat perbatasan keSingapura dan Malaysia bukanlah gejala mobilisasi sosial yang berlangsung baru-baru ini saja. Singapura dan Malaysia sudah menjadi daerah tujuan bagi masyarakat perbatasan di kawasan Kepulauan Batam bahkan dari daerah lain di Indonesia sejak abad ke-14 (Sairin, 2002). Proses tersebut masih berlangsung hingga saat ini. Perpindahan, mobilitas masyarakat di kawasan perbatasan itu telah turut mewarnai kehidupan sosialekonomi masyarakat di Kepulauan Batam.

Orang Melayu yang bermukim atau memilih menjadi warga negara Indonesia yang hidup di Kepulauan Riau seperti di Tanjung Pinang, Pulau Batam, Karimun, Natuna dan termasuk di pulau-pulau kecil yang tersebar di Kepulauan Riau, tak begitu saja putus hubungan atau pekerjaan dengan Singapura dan Malaysia. Hal ini dikarenakan masih adanya ikatan kekeluargaan bagi mereka yang saat ini menjadi warga negara Indonesia dengan sanak famili yang menjadi warga negara Singapura ataupun Malaysia. Dengan situasi seperti ini, kegiatan saling berkunjung, bersilahturahmi pada hari-hari tertentu masih sangat kental dan kerap dilakukan oleh penduduk perbatasan (Deri, 34 tahun, pengemudi motor sangkut di pelabuhan Sekupang dan Belakang Padang. Wawancara pada 12 Desember 2014).

Orang asing yang datang dari Singapura dan atau Malaysia pada umumnya adalah untuk berlibur dan mengunjungi famili yang ada di Kepulauan Batam. Menurut Sairin (2002) praktik mobilitas masyarakat perbatasan -termasuk praktik migrasi antar negara- selalu berkaitan dengan faktor pendorong yang ada di daerah asal dan faktor penarik yang ada di daerah tujuan. Ada berbagai faktor penarik dan pendorong mobilitas antar-negara pada masyarakat perbatasan ke Singapura dan Malaysia. Selain kegiatan melancong, hubungan kedekatan, kekeluargaan dan kerabat menjadi faktor utama secara sosialbudaya bagi masyarakat di kawasan perbatasan yang melakukan mobilitas ke Singapura dan Malaysia. Sementara itu, kesempatan untuk memperoleh kehidupan yang lebih sejahtera di Singapura dan Malaysia memang menjadi tawaran yang menarik bagi banyak tenaga kerja 
di Kepulauan Batam serta Kepulauan Riau di Indonesia untuk melakukan perpindahan atau migrasi ke dua negara tersebut.

Singapura dan Malaysia masih kerap dipandang sebagai dua negara atau kawasan yang posisinya berada lebih tinggi daripada Kepulauan Batam -bahkan Indonesia-baik secara ekonomi, taraf pendidikan warga, maupun kualitas pelayanan di bidang kesehatan. ${ }^{1}$ Jika membandingkan kurs mata uang, nilai Rupiah cenderung selalu berada di bawah mata uang Singapura (SGD 1 = Rp9.700,00) dan mata uang Malaysia (MYR 1 = Rp3.100). Kondisi ini tentu saja berpengaruh terhadap kehidupan warga negara yang tergolong kaya dan maju seperti Singapura (pendapatan per kapitanya sebelas kali lipat daripada Indonesia) dan Malaysia (pendapatan per kapitanya tiga kali lipat daripada Indonesia) dengan masyarakat di Kepulauan Batam, Indonesia. Pada akhir pekan, Kepulauan Batam, khususnya pusat perbelanjaan dan kawasan wisata, kerap diramaikan oleh orang-orang yang datang dari Singapura dan Malaysia dari berbagai etnis suku. Mereka memilih Kepulauan Batam sebagai tempat menghabiskan libur akhir pekan karena kawasan ini berjarak cukup dekat dengan Singapura dan Malaysia (sekitar 45 menit menumpang kapal ferry). Selain itu, juga karena anggapan dan pengalaman bahwa di Kepulauan Batam sangat berbeda dengan di Singapura atau Malaysia. Mulai dari harga produk, harga penginapan, harga makanan yang cenderung lebih murah, hingga berbagai aturan yang tidak terlalu ketat dan mengikat seperti di Singapura atau Malaysia (Hamsani Rahmat, 65 tahun, pensiun Dinas Kesehatan Pemerintah Singapura. Wawancara pada 7 Desember 2014). Oleh karena itu, Kepulauan Batam kerapkali dianggap sebagai kawasan 'surga' bagi orangorang asing yang datang dari Singapura maupun Malaysia.

Singapura termasuk sepuluh negara terkaya di dunia pada 2015 dan pada tahun 2013 Dana Moneter Internasional menetapkan Singapura sebagai negara dengan pendapatan per kapita tertinggi di dunia.

\section{Relasi Ekonomi dengan Negara Tetangga}

Masyarakat perbatasan di Kepulauan Batam mengandalkan produk-produk dari luar negeri seperti Singapura dan Malaysia untuk memenuhi kebutuhan sehari-hari mulai dari kebutuhan primer, sekunder, maupun tersier. Bagi masyarakat perbatasan adalah sesuatu yang lumrah untuk melakukan transaksi ekonomi, jual beli dengan masyarakat dari luar kepulauan tersebut. Hal ini sudah terjadi sejak lama, sejak kawasan kepulauan ini dijadikan sebagai kantong-kantong pelebaran industri Singapura dan Malaysia. Pada era 1950-1970an, masyarakat perbatasan tidak perlu memakai paspor atau surat menyurat lainnya untuk berniaga dengan orang-orang dari negara tetangga. Masyarakat perbatasan yang kebanyakan bekerja sebagai nelayan akan menjual atau membarter hasil tangkapan laut mereka (ikan, kepiting, udang, dan sebagainya) kepada orang-orang pedagang di seberang yang membutuhkannya. Hasil jual ikan dan kepiting itu dibelikan atau dibarter dengan beras, gula, dan sebagainya. Praktik niaga antar-negara ini bukanlah sesuatu yang baru dan asing bagi masyarakat perbatasan. Hubungan ini jamak dilakukan oleh antar-masyarakat perbatasan di Kepulauan Batam secara bebas tanpa aturan dagang lintas kawasan atau negara (Natsir, 61 tahun, nelayan. Wawancara 5 Desember 2014).

Akan tetapi masa-masa itu segera berakhir -paling tidak aturannya tidak sebebas waktu itu- ketika era otonomi daerah ada aturan dan penegakan hukum dalam bidang kapabeanan yang menghendaki masing-masing negara baik Indonesia maupun Singapura dan Malaysia melakukan jual beli di kawasan perbatasan sesuai dengan hukum dagang yang berlaku. Alhasil, masyarakat perbatasan tidak bisa lagi bebas menjual dan membeli barang-barang dari kepulauan tersebut maupun dari negara tetangga. Namun demikian kondisi ini segera berganti dengan diberlakukannya Batam sebagai pelabuhan bebas dan kawasan ekonomi 
bebas. Saat tulisan ini dibuat, kebutuhan pokok masyarakat perbatasan di kawasan Kepulauan Batam didatangkan atau dipasok dari negara tetangga seperti Singapura dan Malaysia. Ada dua faktor yang melatarbelakanginya, pertama, jarak antara Batam dan pulau-pulau kecil di sekitarnya dengan Singapura dan Malaysia lebih dekat daripada dengan Jakarta. Persoalan jarak ini berpengaruh terhadap biaya distribusi seperti ongkos transportasi barang-barang tersebut untuk sampai ke Kota Batam dan daerah di sekitarnya. Jika barang-barang tersebut dipasok dari Jakarta atau Pulau Jawa, setelah sampai di Kota Batam dan pulau-pulau kecil lainnya, harga jualnya akan semakin tinggi. Hal ini berbeda dengan ketika barang-barang tersebut dipasok dari Singapura atau Malaysia yang jarak tempuhnya dengan menggunakan kapal laut hanya memakan waktu sekitar 40-50 menit ke pelabuhan-pelabuhan Kota Batam. Harga jual barang-barang tersebut akan jauh lebih murah ketimbang jika barang-barang tersebut didatangkan dari Jakarta atau Pulau Jawa.

Di kawasan perbelanjaan Jodoh dan Nagoya di Kota Batam, dengan mudah kita akan menemukan keperluan seperti tas tangan, sepatu-sendal, travel-bag, dan sebagainya yang dijual dengan harga miring. Barang-barang tersebut adalah keluaran Singapura yang merupakan produk-produk kelas dua atau kelas tiga (produk $k w$ ) yang pangsa pasarnya lebih banyak di Kota Batam -mengingat Batam sebagai kawasan industri, magnet bagi penduduk untuk mencari kerja. Selain itu, barang-barang kebutuhan sehari-hari seperti beras, gula, minyak makan, makanan ringan, minuman kaleng, dan sebagainya didatangkan dari Singapura atau Malaysia juga. Tentu masih teringat cerita tentang Batam sebagai kawasan 'pembuangan akhir' dari barang-barang habis pakai atau bekas dari negara Singapura dan Malaysia. Beberapa kawasan Batam seperti Bengkong, Batu Hampar, Batuaji dijadikan sebagai kawasan penampung limbah barangbarang bekas pakai orang Singapura seperti kulkas, kipas angin, televisi, belum lagi berbalbal pakaian bekas yang bebas masuk ke Batam dan kawasan sekitarnya.

Faktor kedua ialah penetapan Batam sebagai wilayah perdagangan bebas dan pelabuhan bebas melalui Peraturan Pemerintah Republik Indonesia Nomor 46 Tahun 2007 tentang Kawasan Perdagangan Bebas dan Pelabuhan Bebas Batam. Sejak tahun 2000 Batam sudah menjadi kawasan perdagangan bebas dan pelabuhan bebas yang kemudian dikuatkan dengan Peraturan Pemerintah Pengganti Undang-Undang tahun 2007. Oleh karena itu, barang-barang yang menjadi kebutuhan masyarakat perbatasan di Pulau Batam dan sekitarnya menjadi legal ketika beredar dan dikonsumsi di kawasan Kepulauan Batam. Jika merunut ke belakang, sejak tahun 1969 atau tahun 1979 (era Batam dipimpin oleh BJ Habibie) ketika Batam menjadi daerah penyangga dan penopang kegiatan berbagai perusahaan industri dari Singapura dan Malaysia, tidak mengherankan jika barangbarang dan berbagai produk elektonik dijual dan menyebar luas di Kepulauan Batam. Jamak diketahui bahwa Batam sebagai daerah yang menerima, menampung, dan menjual kembali barang-barang, baik barang baru maupun barang bekas, pada masyarakat perbatasan di Batam dan sekitarnya dari Singapura ataupun Malaysia. Contoh yang paling kentara ialah harga jual beli mobil produk Singapura yang tergolong lebih rendah ketimbang di daerah lain di Indonesia. Kondisi ini mengakibatkan banyaknya mobil bekas dari Singapura yang bertanda $X$ beredar di Kota Batam. Pada tahun 2010 mobil-mobil ini pernah menjadi isu hangat di Batam karena tidak terdaftar di Pemerintah Kota Batam -tidak bertanda $Z$ sesuai dengan aturan di Batam. Hingga tahun 2013 ada sekitar 14 ribu mobil keluaran Singapura yang bertanda $\mathrm{X}$ masih berkeliaran bebas di Kota Batam dan sekitarnya yang belum didaftarkan ke pemerintah daerah (http://otomotif.antaranews.com). 
Agaknya kondisi ini sudah berlangsung sejak lama, mengingat pada awalnya Kepulauan Batam memang secara ekonomi lebih banyak mengandalkan perkembangan perusahaanperusahaan industri dari Singapura dan Malaysia. Batam sudah dilihat sebagai salah satu kawasan industri strategis nasional Indonesia yang terletak di kawasan yang sangat potensial secara ekonomi dan bisnis. Sebagai kawasan strategis, Batam mendapat perlakukan khusus dari pemerintah pusat. Kekhususan Batam erat kaitannya dengan kepentingan pemerintah pusat akan sektor ekonomi, industri, relasi regional-bilateral dengan Singapura dan Malaysia. Ada dua rasionalitas yang melatar-belakangi Batam diberikan skema desentralisasi asimetris. Pertama, posisi strategis Batam karena letaknya pada jalur pelayaran internasional, apalagi letak Batam berbatasan langsung dan dekat dengan Singapura yang kaya. Berkah letak strategis ini akan terkait dengan kapabilitas competitiveness sebuah negara-bangsa dalam kerangka persaingan global dan regional yang semakin keras. Artinya, Batam harus dipersiapkan sebagai duta Indonesia guna menangkap peluang ekonomi Singapura. Kedua, letak Batam yang secara geografik berbatasan langsung dengan Singapura dan Malaysia membutuhkan pengelolaan yang khusus karena ia harus dilengkapi dengan instrumen untuk meminimalisasi 'resiko' sebagai kawasan-kawasan perbatasan yang mengandung resiko bagi keamanan negara dan keutuhan teritorial negara-bangsa (Karim dkk, 2010).

Merespon desentralisasi asimetris yang diberikan kepada Batam, pemerintah menyiapkan instrumentasi dari kebijakan asimetris desentralisasi tersebut dalam bentuk kerangka regulasi yang kemudian diterapkan kepada Batam. Respon kebijakan yang diberikan pusat kepada Batam itulah yang membentuk Batam sebagai salah satu kawasan pengembangan ekonomi sesuai dengan motif ekonomi yang melatarbelakangi pemberian skema asimetrisme ini. Dengan pertimbangan itu, pemerintah pusat kemudian menghadirkan kawasan otorita di Batam. Otorita Batam merupakan organ pusat yang dicangkokkan di daerah. Ada kepentingan pemerintah yang cukup kuat terhadap arah pengembangan Batam sebagai kota perdagangan dan jasa. Ada enam periode dalam proses pengembangan Batam sebagai kawasan ekonomi bagi Indonesia, yakni pertama, periode persiapan (1969-1975) yang dipegang oleh Ibnu Sutowo; kedua, periode konsolidasi (1975-1978) oleh J.B Soemarlin; ketiga, periode pemantapan rencana (19781998) oleh B.J Habibie; keempat, periode penanaman modal (Maret 1998-Juli 1998) oleh J.E Habibie; kelima, periode kesejahteraan rakyat (Juli 1998-April 2005) oleh Ismeth Abdullah; dan terakhir keenam, periode penanaman modal dan kualitas lingkungan hidup (April 2005-sekarang) oleh Mustofa Wijaya (Karim dkk, 2010; BIFZA, 2014).

Kepulauan Batam dan kawasan sekitarnya menjadi tujuan penanaman modal bagi investor asing dari luar negeri, khususnya dari Singapura. Dari 707 perusahaan yang bermukim di Batam, 468 perusahaan tersebut dimiliki dan dikelola oleh Singapura langsung dari seberang Pulau Batam. Mayoritas perusahaan tersebut bergerak di bidang industri pengolahan yang bahan bakunya sudah pasti disuplai dari beberapa pulau kecil di Batam dan kawasan lain di Indonesia. Nilai investasi Singapura di Batam nyaris menembus $2 / 3$ dari total investor di sana yakni sebesar US\$ 1,06 milyar per Juni 2014. Sebanyak 79,32 persen investasi di Batam didominasi oleh pihak swasta dan 58,14 persen dari total investasi tersebut dikuasai oleh investor asing. Pada semester I tahun 2015, investasi di Batam naik dan menembus angka 300 persen ketika dibandingkan tahun 2014 (http://batampos.co.id). 


\section{Melayu sebagai Simpul Penyatu Tiga Kawasan Lintas Negara}

Masyarakat perbatasan di Kepulauan Batam terdiri atas berbagai etnis suku dari berbagai kawasan di Indonesia. Mulai dari suku Jawa, Sunda, Minang, Batak, Flores, Bugis, dan Melayu -termasuk Melayu Lautserta keturunan Tionghoa yang tak kalah banyaknya. Melayu di kawasan perbatasan di Kepulauan Batam tidak saja merupakan etnis mayoritas, tetapi juga menjadi rujukan sosial-budaya bagi masyarakat setempat. Sebagai etnis mayoritas, etnis yang datang ke kawasan ini misalnya dari Jawa, Minang, Bugis dan sebagainya menyesuaikan adatistiadat dengan kebudayaan Melayu. Seperti, cara berkomunikasi termasuk bahasa yang digunakan, masakan yang dimakan sehari-hari, falsafah hidup sehari-hari, dan sebagainya. Pada umumnya, etnis di luar Melayu yang hidup di kawasan ini beradaptasi dengan kebudayaan Melayu. Hal ini semakin kuat ketika terjadi perkawinan silang antar-suku di kawasan perbatasan tersebut. Misal pemuda Melayu menikah dengan pemudi beretnis Sunda, mereka menikah dengan adat Melayu. Akan tetapi putusan-putusan ini sifatnya tidaklah statis, selalu ada perundingan antarkedua belah pihak (Cucum Suminar, 33 tahun, pegawai swasta. Wawancara 19 Juli 2015).

Sistem kekerabatan dan lokalitas cenderung diwarnai oleh tradisi-tradisi etnis Melayu. Unsur-unsur budaya baru yang diserap dari kehidupan masyarakat lokal segera menjadi bagian penting bagi masyarakat pendatang di pulau tersebut. Dominan tidaknya unsur budaya lama yang masih mewarnai kehidupan para pendatang etnis di luar kawasan perbatasan tentu sangat tergantung dari partisipasi mereka dalam kehidupan masyarakat. Selain tingkat partisipasi atau keber-baur-an, hal ini juga dipengaruhi oleh rentang waktu masyarakat pendatang tinggal dan menetap di kawasan tersebut. Diperkirakan bahwa semakin tinggi tingkat partisipasi mereka dalam kehidupan masyarakat setempat akan semakin mudah pula mereka meninggalkan sebagian dari unsur-unsur budaya lama yang pernah menjadi bagian dalam kehidupan mereka. Sebaliknya semakin rendah tingkat partisipasi mereka dalam kehidupan masyarakat setempat akan semakin sulit pula bagi mereka untuk meninggalkan unsur-unsur budaya lama mereka. Selain itu, rentang waktu juga mempengaruhi pola kehidupan sosial dan budaya mereka. Semakin lama mereka tinggal dan bergaul dalam masyarakat setempat akan semakin mudah pula bagi mereka untuk menyerap unsur-unsur budaya masyarakat lokal dan dengan sendirinya akan semakin mudah pula pengaruh unsur-unsur budaya tradisional mereka lupakan. Semisal, orangorang Bugis yang sudah tinggal di kawasan Kepulauan Batam sejak tahun 1970 dan tak lagi pernah kembali ke tanah Bugis di Sulawesi, sudah menjadi seperti orang-orang Melayu yang kehidupan sosial-kulturalnya merupakan bagian dari etnis Melayu.

Sementara itu bagi, penduduk lokal yang lahir dan besar di kawasan perbatasan di Kepulauan Batam yang beretnis Melayu, kemelayuan dipandang sebagai sesuatu yang lebih besar dan luas ketimbang hanya sebagai salah satu suku bangsa yang ada di Indonesia, Singapura atau Malaysia. Etnis Melayu yang tersebar pada tiga negara ini dipandang sebagai simpul pengikat, penyatu terutama bagi orang-orang Melayu yang tersebar lintas negara di Singapura dan Malaysia. Hal ini diperlihatkan dalam praktik kehidupan keseharian masyarakat perbatasan. Ketika harihari besar, seperti lebaran Idul Fitri, Idul Adha, salah satu pulau kecil di Kepulauan Batam yakni Pulau Penawar Rindu di Kecamatan Belakang Padang, selalu dipenuhi oleh orangorang Melayu yang datang berlebaran dari Singapura dan Malaysia. Lebaran yang identik dengan tradisi pulang kampung, dimaknai oleh mereka sebagai ajang berbagi bantuan sosial kepada orang-orang di kampung halaman. 
Bukan sesuatu yang baru bagi penduduk di pulau kecil ini bahwasanya anggota keluarga mereka berbeda warga negara, entah ibu, entah kakak, entah sepupu, dan sebagainya. Hal ini sudah menjadi umum ditemui dan akrab bagi mereka. Menjaga persatuan masyarakat di bawah kemelayuan dan kekeluargaan menjadi lebih utama dan penting ketimbang perbedaan warga negara.

Gagasan nasionalisme terhadap Indonesia yang dipahami seperti berupa cinta produk dalam negeri atau cinta rupiah bagi masyarakat perbatasan akan terlihat agak janggal dan menggelikan. Karena, kebutuhan hidup masyarakat dipenuhi justru oleh produkproduk dari Singapura dan Malaysia. Sementara mata uang kedua negara tetangga tersebut sehari-hari berseliweran di warung-warung, kafe-kafe, penginapan-penginapan di kawasan perbatasan. Lihat saja di sudut-sudut kota Batam, di sepanjang trotoar pusat perbelanjaan, gerai-gerai penukaran uang cukup banyak dan beroperasi hampir dua puluh empat jam. Bayangan nasionalisme masyarakat perbatasan di Kepulauan Batam ini agaknya tidak dapat disederhanakan dari persoalan konsumsi produk dalam atau luar negeri, pun juga pemakaian mata uang yang tidak didominasi oleh rupiah, apalagi persoalan multibahasa (multilingual) yang kerap mereka lakukan dalam komunikasi sehari-hari -hal ini cenderung dipraktikkan oleh etnis MelayuTionghoa. Pun dengan kecenderungan orangorang perbatasan yang memilih berobat ke Singapura atau Malaysia, bukan karena di kawasan ini tidak tersedia pelayanan kesehatan. Kepulauan Batam sendiri memiliki sejumlah delapan unit rumah sakit yang enam unitnya dikelola oleh pihak swasta. Ada seratus enam puluh enam balai pengobatan yang tersebar pada dua belas kecamatan di Kepulauan Batam yang didominasi oleh pihak swasta. Akan tetapi kecenderungan berobat ke Singapura dan Malaysia tetap cukup tinggi dengan pertimbangan ongkos yang dikeluarkan berobat di Kepulauan Batam sama atau beda tipis dengan berobat di negara tetangga dengan kualitas yang lebih baik.

Dominasi ekonomi Singapura dan Malaysia di kawasan perbatasan Kepulauan Batam tidak serta merta membuat orang-orang di perbatasan mengganti kewarganegaraan mereka menjadi warga asing. Kesetiaan pada Indonesia tetaplah tinggi mesti kecintaan itu beririsan dengan aspek kemelayuan yang sifatnya lintas negara, lintas teritori. Jamak diketahui, kawasan perbatasan di Indonesia kerapkali dibangun dengan pendekatan keamanan dengan menyebarkan unsur militer di sepanjang kawasan perbatasan. Hal ini berkaitan dengan logika pemerintah pusat yang ingin menampilkan Indonesia di perbatasan secara tegas, berani, dan terkesan aman (Sanak, 2011). Hal yang mirip sebenarnya terjadi di kawasan perbatasan Kepulauan Batam. Pulau Penawar Rindu, Kecamatan Belakang Padang, salah satu pulau deretan paling depan yang berhadapan dengan Singapura; menginjakkan kaki pertama kali di pelabuhan pulau ini kita akan disuguhkan dengan pemandangan yang sangat militeristik. Pos TNI AL, Pos Polisi, Pos Koramil tegak berderetan di bibir gerbang pulau ini. Pos-pos ini berdekatan dengan kantor pos, pasar, dan pemukiman penduduk. Hal ini menjelaskan bahwa negara Indonesia selalu mengingatkan penduduk perbatasan di sana sebagai warga negara dan menjadi bagian dari Negara Kesatuan Republik Indonesia yang berbeda dengan Singapura atau Malaysia. Pemandangan yang militeristik ini sebenarnya juga berkaitan dengan kisah heroik kepahlawanan masyarakat Indonesia ketika berhadapan dengan Jepang pada Perang Dunia II maupun ketika terjadi gesekan antara Indonesia dengan Malaysia pada tahun 1960an. Bayangan ini juga turut membentuk kecintaan, rasa memiliki, dan pembelaan terhadap Indonesia sehingga tetap ada pada masyarakat perbatasan (Liat Heng, 64 tahun, pedagang makanan dan penyedia jasa perahu pancung. Wawancara 6 Desember 2014). 


\section{Kesimpulan}

Masyarakat perbatasan di Kepulauan Batam membayangkan nasionalisme terhadap Indonesia itu secara 'khas' dan berbeda dengan masyarakat yang berada di kawasan non-perbatasan atau kawasan perbatasan non-laut di Indonesia. Masyarakat perbatasan dalam membayangkan nasionalisme tidak bisa dilepaskan dari pertalian atau kedekatan budaya dengan masyarakat dari negara tetangga Singapura dan Malaysia. Selain ikatan dan kedekatan budaya, masyarakat perbatasan juga mesti berhadapan dengan kondisi perekonomian atau relasi ekonomi yang cenderung masih didominasi oleh dua negara tetangga tadi, Singapura dan Malaysia. Dalam hal pertalian atau kedekatakan budaya, dalam membayangkan nasionalisme terhadap Indonesia, masyarakat perbatasan tidak bisa dilepaskan dari Melayu sebagai simpul pengikat secara sosial dan budaya yang sudah menyejarah sejak berabad silam di kawasan perbatasan ini. Melayu dan kemelayuan menjadi raison d'etre bagi masyarakat perbatasan untuk mendefinisikan diri mereka secara sosial dan politik yang berelasi dengan banyak hal dan kepentingan yang sifatnya tidak saja domestik tapi juga lintas-negara. Melayu tersebar pada tiga kawasan tersebut yang berbeda sama sekali secara geo-politik. Orang Melayu yang berada di Pulau Penawar Rindu merupakan warga negara Indonesia, yang berinteraksi secara intens dengan sesama orang Melayu yang merupakan warga negara dari Singapura dan Malaysia. Selain interaksi, masyarakat perbatasan juga melakukan mobilitas yang cukup tinggi ke negara tetangga, seperti masih memiliki ikatan kerabat di negeri seberang. Kondisi seperti ini sudah dipraktikkan sejak masa lalu ketika hubungan Indonesia dengan Malaysia dalam keadaan mesra dan hangat (pra-konfrontasi dengan Malaysia). Pun jika ingin membingkainya dalam perspektif sejarah, sejak zaman Kesultanan Malaka pada abad 14-15, masyarakat di tiga kawasan ini sudah berbaur dan terbuka dengan berbagai perbedaan etnis dan agama.

Persoalan ekonomi agaknya tidak cukup untuk menjelaskan bayangan nasionalisme terhadap Indonesia. Relasi yang erat bahkan ketergantungan yang cukup tinggi secara ekonomi dengan negara tetangga, tidak dapat serta merta dikatakan membuat masyarakat perbatasan ingin pindah, menetap, dan menjadi penduduk Singapura ataupun Malaysia. Buktinya, rasa nasionalisme itu dijelaskan melebihi dari sekadar pemenuhan kebutuhan ekonomi yang memang ditopang oleh negara tetangga. Masyarakat perbatasan mengaku mencintai dan membela Indonesia dengan kondisi yang 'terbelah', karena pada saat yang bersamaan juga beririsan dengan kemelayuan yang sifatnya lintas negara. Masyarakat perbatasan di Kepulauan Batam secara geopolitik merupakan penduduk Indonesia. Akan tetapi, pertalian dan kedekatan bersama di bawah payung Melayu mengalahkan kekuatan ideologi negara dan teritori yang memisahkan masyarakat perbatasan, baik Indonesia, Singapura maupun Malaysia. Tidak berarti masyarakat perbatasan tidak cinta Indonesia atau tidak nasionalis. Pengalaman sejarah dan pengalaman kultural bersama inilah yang kemudian memberikan warna, corak, atau kekhasan tersendiri bagi masyarakat perbatasan ketika membayangkan atau mendefiniskan nasionalisme tersebut.

\section{Daftar Pustaka}

Anderson, Bennedict. 2001. Imagined Communities: Komunitas-komunitas Terbayang. Terjemahan Omi Intan Naomi. Yogyakarta: Insist Press.

Batam Dalam Angka 2014. Laporan Badan Pusat Statistik Kota Batam.

Batam Indonesia Free Zone Authority (Badan Pengusahaan Kawasan Perdagangan Bebas dan Pelabuhan Bebas Batam). Development Progress of Batam. Edisi I Volume XXV, 2014. Diterbitkan oleh Pusat Pengolahan Data 
dan Sistem Informasi (PPDSI) BP KPBPB Batam.

Barker, Chris. 2000. Cultural Studies: Theory and Practice. London: Sage Publication Ltd.

Karim, Abdul Gaffar, dkk 2010. Desentralisasi Asimetris di Indonesia: Praktek dan Proyeksi. Laporan Akhir Penelitian dari Jurusan Politik dan Pemerintahan FISIPOL Universitas Gadjah Mada bekerja sama dengan Yayasan Tifa.

Giddens, Anthony. 1985. The Nation-State and Violence. Cambridge: Polity Press.

Marsetio. 2012. Konstruksi Marginalitas Daerah Perbatasan (Studi Kasus Kepulauan Natuna). Disertasi. Universitas Gadjah Mada: Yogyakarta.

Reid, Anthony. 2010. Sumatera Tempo Doeloe: dari Marco Polo sampai Tan Malaka. Depok: Komunitas Bambu.

Sairin, Sjafri. 2002. Perubahan Sosial Masyarakat Indonesia: Perspektif Antropologi. Yogyakarta: Pustaka Pelajar.

Samad, Raja Sofyan. 2010. Negara dan Masyarakat: Studi Penetrasi Negara di Riau Kepulauan Masa Orde Baru. Yogyakarta: Pustaka Pelajar.
Sanak, Yohanes. 2011. Human Security $\mathcal{E}$ Politik Perbatasan. Research Centre for Politics and Goverment, Jurusan Politik dan Pemerintahan, Universitas Gadjah Mada. Yogyakarta.

Sunardi, R. M. 1997. Teori Ketahanan Nasional. Jakarta: Hastannas.

Sensus Penduduk Tahun 2000. Badan Pusat Statistik Republik Indonesia.

Sunardi, R.M. 1997. Teori Ketahanan Nasional. Jakarta: Hastannas.

Weeks, J. 1990. "The Value of Difference" dalam J. Rutherford (ed). Identity: Community, Culture, Differences. London: Lawrence \& Wishart.

\section{Internet}

http://batampos.co.id/14-08-2015/637perusahaan-masuk-batam/ diakses pada 25 Desember 2015 pukul 11.00 WIB.

http://otomotif.antaranews.com/berita/358055/ ham pir-14-ribu-mobil-eks-singapurabelum-registrasi. Diakses pada 26 Desember 2015 pukul 16.00 WIB. 